\title{
Effect of Continuous Grazing on the Diet of
} Steers

\author{
DAVID A. YATES, D.C. CLANTON, J.T. NICHOLS
}

\begin{abstract}
Continuous grazing of Sandhill native forage at a normal stocking rate in late August had no effect on organic matter intake (OMI), but the protein content and in vitro organic matter digestibility (IVOMD) declined over a 3-week period. The average OMI was $75 \mathrm{~g} / \mathrm{kg} \mathrm{W}^{.75}$. As the availability of forage declined, the ability of the steers to selectively graze was apparently reduced. Similarly, continuous grazing of mixed prairie-type range from October 30 to March 13 had no effect on OMI but the protein content of the diet was reduced. The IVOMD did not change during the winter grazing trial. The a verage $O M I$ was $66 \mathrm{~g} / \mathrm{kg} \mathrm{W}^{75}$ Steer calves gained .24 $\mathrm{kg}$ daily during the grazing period.
\end{abstract}

Crampton et al. ( 1960 ) stated, "Of all 6000 feeds thus far studied. forages continue to present the greatest problem of a meaningful quantitative description of their nutritive value." Nutritive value is the product of quantity and quality of the diet consumed by grazing animals. Crampton et al. (1960) also stated, "The importance of the relative intake of a forage as compared to its digestibility in determining the numerical value of the Nutritive Value Index is approximately 70 vs $30 \%$, respectively."

The best assessment of the qualitative value of the diet of a grazing animal is determined using forage samples collected by esophageal fistula (Lesperance et al. 1974, Kartchner and Campbell 1979).

The quantity of forage consumed by the grazing animal can be measured indirectly using indicators (Harris et al. 1967, Raleigh et al. 1980) with or without total fecal collection (Kartchner and Campbell 1979).

Many factors, i.e., weather, type of forage, chemical composition, and plant maturity, have been associated with the quantity and quality of the grazing animal's diet. An excellent review of these factors appears in the work of Kartchner and Campbell 1979. The effect of continuous grazing on voluntary forage intake and diet quality have not been studied extensively on native range, especially Sandhills or mixed-prairie type vegetation.

The objective of the research reported here was to study the effect of continuous grazing on the quantity and quality of steer diets when grazing Sandhills range in late summer or mixed-prairie type range during the winter.

\section{Materials and Methods}

Two experimental pastures of different vegetation types, located in west central Nebraska, were used for two separate grazing trials. Both study areas were located within the 43 to $48-\mathrm{cm}$ precipitation zone. Stocking rates were calculated for each study area in accordance with site potential and range condition class as suggested by Soil Conservation Service guidelines. Pastures were fully stocked

Authors are former graduate assistant in animal science (now Extension specialist in animal science, Univ. of Wyoming), professor of a nimal science and professor of agronomy (range and forage), Univ. of Nebiaska North Platte Station, Nonh Platte.

Authors wish to acknowledge the assistance of Research Technicians G.L. Walker, M.E. England, M.J. Knott, and R.L. Davis. Published as Paper No. 6038 Journal Series, Nebraska Agr. Exp. Sta. according to their productive potential to approximate normal stocking rates and forage availability under ranching conditions. Grazing trials were conducted during late summer and winter when the forage was mature, thus not having the potential for regrowth. This was important to insure that the quantity of forage was declining as the animals grazed and to eliminate the possibility of new growth confounding the quality of the animals' diet. Pastures were not grazed during the growing season proceding the start of the grazing trials.

Five yearling esophageal fistulated steers were used for diet and fecal collections in each trial. Diet samples and total fecal collections using bags were made over a 5-day period. Fecal collections were initiated 2 days after diet sampling started. Steers were not fasted prior to sampling of grazed forage. Diet samples were collected during approximately $\mathbf{4 5}$ minutes of grazing time early in the morning. Fecal collections were made twice daily. Fecal subsamples were composited into one sample per day for each steer.

All samples were weighed, thoroughly mixed, subsampled, identified, and stored frozen for further analysis. The frozen samples were allowed to thaw 6 hours before being placed in a forced-air oven and dried at $45^{\circ} \mathrm{C}$. Samples were allowed to equilibrate at room temperature for 2 days. Fecal samples were then weighed for determination of air-dry fecal output.

Diet and fecal samples were ground through a 20 -mesh screen in a Wiley Mill prior to analysis for dry matter and ash. Diet samples were analyzed for crude protein (CP) according to A.O.A.C. (1975). In vitro organic matter digestibility (IVOMD) determinations were made on diet samples using the Barnes (1969) revision of the Tilley and Terry (1963) procedure. Organic matter intake (OMI) was determined using the following calculations:

$$
\mathrm{OMI}=\frac{\mathrm{Kg} \text { fecal organic matter ouput }}{\% \text { indigestible diet organic matter }}
$$

Data were statistically analyzed using least squares analysis of variance as outlined by Harvey $(1960)$. When significant $(P<.05)$ $F$-values were found, means were contrasted using orthogonal contrasts to the third degree (Steel and Torrie 1960).

\section{Trial I}

The first trial was conducted at the University of Nebraska Sandhills Agricultural Laboratory $14 \mathrm{~km}$ northeast of Tyron, Neb. The study area was on a sands range site with soils classified as Valentine fine sands. Range condition was classified as good (58\%) with predominant grass species being switchgrass (Panicum virgatum), prairie sandreed (Calamovilfa longifolia), little bluestem Schizachyrium scoparium), needleandthread (Stipa comata), sand bluestem (Andropogon hallii), and blue grama (Bouteloua gracilis). The stocking rate was based on the commonly accepted rate of $1.48 \mathrm{AUM} /$ ha which calculated to be .33 ha per animal for the 21-day trial. The 21-day trial, August 15 through September 4, 1977, was divided into three 7-day collection periods.

The esophageal-fistulated steers were grazed on an adjacent pasture of similar range condition 10 days prior to the beginning of 
the trial. The steers were transferred to the 2-ha experimental pasture the night previous to the beginning of the trial.

\section{Trial II}

The second trial was conducted at the University of Nebraska North Platte Station, North Platte, Neb. The study area supported a mixed prairie type vegetation. The topography is rough and characterized by steep slopes and sharp breaks. Soils are primarily silt loams. The uplands were dominated by blue grama, needleandthread and thread-leaf sedge (Cares filifolia), as well as numerous other species of lesser importance, i.e., prairie sandreed (Calamovilfa longifolia), junegrass (Koleria cristata), sand dropseed (Sporobolus cryptandrus), small soapweed (Yucca glauca), and some perennial forbs. The sharp breaks, sometimes characterized by limey parent material outcrops, support stands of little bluestem, sideoats grama (Bouteloua curtipendula), hairy grama Bouteloua hirsuta), big bluestem (Andropogon gerardi), blue grama, and numerous perennial forbs. The narrow bottoms are dominated by western wheatgrass (Agropyron smithii), blue grama, big bluestem, and scattered areas of snowberry (Symphorocarpus spp.). The upland range sites are predominately classified as silty and the narrow bottoms as overflow.

Five esophageal-fistulated steers grazed winter-long with 25 weanling steer calves in a 32 -ha pasture. The trial lasted from October 30, 1977, through March 13, 1978. Five collection periods were conducted during the following dates: October 30 through November 5; December 1 through 7; January 2 through 8; February 3 through 9 ; and March 7 through 13. All animals received .68 $\mathrm{kg}$ of a $40 \%$ natural protein supplement each day. Cattle were fed hay when snow prevented grazing. The fistulated steers were individually fed supplement 1 week prior to and during the collection period.

Fistulated steers were grazed on an adjacent pasture for 3 weeks before being transferred to the experimental pasture 2 days prior to the start of Trial II. The steers and calves were gathered early in the morning for supplement feeding. Fistulated steers were prepared for diet sample collections and total fecal collections. The fistulated steers were then transported in a stock trailer to the area being grazed the previous afternoon and evening for diet sampling. At the end of each collection period all cattle were weighed in the morning after being off feed and water overnight.

When supplement was fed, OMI of forage was calculated after deducting the amount of organic matter (OM) in the feces resulting from the supplement fed. This was accomplished by multiplying the amount of $O M$ in the supplement by its percent indigestibility and subtracting from the total fecal OM.

\section{Results and Discussion}

\section{Trial I}

Organic matter intake, IVOMD and CP of steer diets were not different $(P>.05)$ among animals. The means and standard errors for OMI $\left(\mathrm{g} / \mathrm{kg} \mathrm{W}^{.75}\right)$, IVOMD $(\%)$, and protein $(\%)$ of grazed forage were $75 \pm 5,60 \pm 1$, and $7.9 \pm .3$, respectively. In cont rast, Rittenhouse (1969) found differences $(P<.01)$ among animals for forage intake when grazing the same pasture, but found no animal differences $(P>.10)$ in IVOMD or protein content. Differences in experimental procedures among researchers may partially explain the animal variability in intake. For example, Rittenhouse (1969) used chromic oxide as an external indicator to measure intake. A correction factor for incomplete $\mathrm{Cr}_{2} \mathrm{O}_{3}$ recovery was determined from total fecal collections on a few animals. This may explain why animal variability for intake measurement reported by Rittenhouse was significant $(P<.05)$.

\section{Intake of Forage}

Intake of the grazing steers expressed as grams $\mathrm{OM} / \mathrm{kg} \mathrm{W} \mathrm{W}^{.75}$ increased linearly $(P<.05)$ from period 1 through period 3 (Table 1). Average intake as a percent of body weight was $1.6 \%$. This value agrees with dry matter intake requirements for steers at maintenance (N.R.C. 1976). Steers in this study just maintained their
Table 1. Average OMI, CP, and IVOMD of grazed forage within each of the three sampling periods (Trial I).

\begin{tabular}{lccc}
\hline \hline Period & $\begin{array}{c}\text { OMI } \\
\left(\mathrm{g} / \mathrm{kg} \mathrm{W}^{.75}\right)\end{array}$ & $\begin{array}{c}\text { CP } \\
(\% \text { of OM) }\end{array}$ & $\begin{array}{c}\text { IVOMD } \\
(\%)\end{array}$ \\
\hline I (Aug. 15 - Aug. 21) & $65^{\prime}$ & $8.9^{\prime}$ & $62^{\prime}$ \\
2 (Aug. 22 - Aug. 28) & 81 & 7.7 & 60 \\
3 (Aug. 29 - Sept. 4) & 79 & 7.3 & 58 \\
$S$ ㅈ & 3.8 & .21 & .56 \\
\hline
\end{tabular}

'The relationship among means within a column is linear $(R<.05)$.

weight throughout the 3-week period. The removal of forage by continuous grazing did not reduce intake.

\section{Protein Content}

Daily CP content of the diet within each period was not consistently different; however, the CP decreased linearly $(P<.05)$ from period 1 through period 3 (Table 1). This decline in CP was probably due to reduced forage availability which limited the ability of the animals to select a higher quality diet. This agrees with work reported by Obioha (1967), Campbell et al. (1968), and Barth and Kazzal (197l) from grazing trials with cattle.

Lake (1974) and Yates and Wallace (1978) found that daily diet CP decreased linearly as available forage decreased in irrigated pasture studies. It should be noted that their studies were with either pure stands of grass or pastures with only two species of grass. Comparable studies on native range have not been reported, but the same response would be anticipated on a less pronounced scale.

\section{Organic Matter Digestibility}

IVOMD of cattle diets decreased linearly $(P<.05)$ for periods I through 3 (Table 1). These values are in agreement with those of Streeter et al. (1968). They found that diet dry matter digestibility values were 54 to $60 \%$ from steers grazing western Nebraska shortgrass-type range in August. They also reported that diet digestibility decreased as the summer grazing season progressed.

A linear relationship $(P<.05)$ existed between forage digestibility over days during period I. Mean IVOMD values on a percentage basis were $64,64,63,59$, and 59 , for days 1 through 5 , respectively. There were no differences in periods 2 and 3 . Arnold (1960) stated that grazing animals preferentially graze those plants or plant parts that result in the highest quality diets. As available forage declined, the ability of the steers to selectively graze was apparently reduced. This agrees with the findings of Arnold (1960). Burzlaff and Clanton (1971) studied quality changes in standing forage on upland-type Sandhills range from July through January of 1962 and 1963. It would appear that the small changes in digestibility and protein content of the standing forage in August reported in their study would not account for all the quality changes reported here.

\section{Trial II}

Organic matter intake, IVOMD and CP of steer diets were not different $(P>.05)$ among animals in Trial 11 . The mean and standard errors for OMI $\left(\mathrm{g} / \mathrm{kg} \mathrm{W}^{.10}\right)$, IVOMD $(\%)$, and protein $(\%)$ of grazed forage were $66.7 \pm 2.4,48 \pm 1$, and $5.3 \pm .2$, respectively.

\section{Intake of Forage}

The OMI expressed as $\mathrm{g} / \mathrm{kg} \mathrm{W}^{.75}$ showed a quadratic relationship $(P<.05)$ over periods (Table 2$)$.

Intake $\left(79 \mathrm{~g} / \mathrm{kg} \mathrm{W}^{75}\right)$ du ring period 2 was higher than the intake for the other periods. There was no explanation for this higher intake but it undoubtedly contributed to the quadratic effect.

The average forage OMI throughout the trial was $66 \mathrm{~g} / \mathrm{kg} \mathrm{W}^{75}$. This intake would provide maintenance for a $422 \mathrm{~kg}$ steer (N.R.C. 1976). Intake values reported by Rittenhouse et al. (1970) on the same experimental pasture were $30 \mathrm{~g}$ dry matter $/ \mathrm{kg} \mathrm{W}^{75}$ during inclement weather with snow cover, and $57 \mathrm{~g}$ dry matter $/ \mathrm{kg} \mathrm{W}^{.75}$ during nice weather with open grazing. Scales et al. (1974) reported 
Table 2. Average OMI, CP, and IVOMD of grazed forage within each of the five sampling periods (Trial 2).

\begin{tabular}{lccc}
\hline \hline Period & $\begin{array}{c}\text { OMI } \\
\left(\mathrm{g} / \mathrm{kg} \mathrm{W}^{75}\right)\end{array}$ & $\begin{array}{c}\text { CP } \\
(\% \text { of OM) }\end{array}$ & $\begin{array}{c}\text { IVOMD } \\
(\%)\end{array}$ \\
\hline 1 (Oct. 30 - Nov. 5) & $62^{1}$ & 8.61 & $46^{2}$ \\
2 (Dec. 1 - Dec. 7) & 79 & 5.6 & 52 \\
3 (Jan. 2 - Jan. 8) & 62 & 4.7 & 46 \\
4 (Feb. 3 - Feb. 9) & 69 & 3.8 & 48 \\
5 (Mar. 7 - Mar. 13) & 61 & 3.7 & 45 \\
$S$ ( & 2.4 & .17 & .5 \\
\hline
\end{tabular}

I Means within a column follow a quadratic relationship $(P<.05)$

-Means within a column follow a cubic relationship $(P<.05)$.

intake values of $47 \mathrm{~g}$ dry matter $/ \mathrm{kg} \mathrm{W}^{.75}$ on mixed prairie-type range in northeastern Colorado. If their dry matter intake values were adjusted to OMI they would be somewhat lower.

\section{Protein Content}

In period 1 and 2, average daily $C P$ of the diet samples was quite variable. The $\mathrm{CP}$ for days 1 through 5 in period 1 were $7.1,7.0,8.7$, 8.9 , and $11.6 \%$, respectively. In period 2 they were $7.3,5.2,5.1,5.4$, and 4.9 , respectively. The large daily variation in period 1 may have been a reflection of inadequate animal adjustment to the experimental pasture. Daily changes in CP of diet samples, for periods 3 , 4 , and 5 , were not different $(P>.05)$. Lack of daily diet differences in CP during the last three periods may be due to a lack of higher quality forage available from which to selectively graze.

The average $C P$ of the samples of grazed forage decreased $(P<.05)$ from periods 1 through 5 . The decline in $C P$ in the animals diet as the winter progressed reflected the lower content in the forage and the fact that cattle probably grazed the higher quality forage first.

Scales et al. (1974) found that steer diets decreased in CP as availability of forage decreased. Their mean protein values for December, January and February were 5.9, 5.7, and 4.7\%, respectively.

\section{Organic Matter Digestibility}

Significant $(P<.05)$ average daily variations of IVOMD occurred in periods 1,2 and 4 . Considerable daily variation could be expected. There was a significant $(P<.05)$ period effect on IVOMD (Table 2). It appeared to be a period to period difference with no specific trend such as was shown with the protein content of the diet.

Scales et al. (1974) found the average digestible energy content of grazed forage from short grass-type winter range to be $41 \%$. Rittenhouse et al. (1970) collected diet samples with esophageal fistulated cattle on the same pasture used in Trial II. They determined an average dry matter digestibility of $39 \%$. Had their data been corrected to organic matter digestibility it would have been quite similar to the values found in this study.

\section{Weight Gains}

Intact steer calves with a mean weight of $192 \mathrm{~kg}$ gained an average of $.24 \mathrm{~kg}$ daily during the winter grazing trial. Intake estimates by yearling fistulated cattle averaged $66 \mathrm{~g} \mathrm{OM} / \mathrm{kg} \mathrm{W}^{.75}$ during the trial. Weanling steer calves gaining $.24 \mathrm{~kg}$ per day should consume approximately $89 \mathrm{~g}$ dry matter $/ \mathrm{kg} \mathrm{W}^{.75}$ (N.R.C. 1976). This would correct to near $82 \mathrm{~g}$ organic matter. The forage intake estimated tends to support the actual weight gains of the grazing steer calves.

\section{Literature Cited}

A.O.A.C. 1975. Official Methods of Analysis (12th ed.). Association of Official Agricultural Chemists. Washington, D.C.

Arnold, G.W. 1960. Selective grazing by sheep of two forage species at different stages of growth. J. Agr. Res. 11:1026.

Barth, K.M., and N.J. Kazzal. 1971. Separation of true selective grazing by cattle from effects of the esophageal fistula. J. Anim. Sci. 33:1124.

Barnes, R.F. 1969. Collaborative research with the two-stage in vitro technique (paper N). Proc. Nat. Conf. on Forage Eval. and Util., Lincoln, Neb.

Burzlaff, D.F., and D.C. Clanton. 1971. The production of upland hay in the Sandhills of Nebraska. Nebraska Agr. Exp. Sta. Res. Bull. SB-517.

Campbell, C.M., K.S. Eng, A.B. Nelson, and L.S. Pope. 1968. Use of esophageal fistula in diet sampling with beef cattle. J. Anim. Sci. 27:231.

Crampton, E.W., E. Donefer, and L.E. Lloyd. 1960. A nutritive value index for forages. J. Anim. Sci. 19:538.

Harris, L.E., C.J. Kercher, G.P. Lofgreen, R.J. Raleigh, and V.R. Bohman. 1967. Techniques of research in range livestock nutrition. Utah Agr. Exp. Sta. Bull. 271.

Harvey, W.R. 1960. Least squares analysis of data with unequal subclass numbers. U.S. Dep. Agr., Agr. Res. Serv. 20-8.

Kartchner, R.J., and C.M. Campbell. 1979. Intake and digestibility of range forages consumed by livestock. Montana Agr. Exp. Sta. Bull. 718.

Lesperance, A.L., D.C. Clanton, A.B. Nelson, and C.B. Theurer. 1974. Factors affecting the apparent chemical composition of fistula samples. Nevada Agr. Exp. Sta. Bull. T 18.

Lake, R.P., D.C. Clanton, and J.F. Karn. 1974. Intake, digestibility and nitrogen utilization of steers consuming irrigated pastures as influenced by limited energy supplementation. J. Anim. Sci. 38:1291.

N.R.C. 1976. Nutrient Requirements of Domestic Animals, No. 4. Nutrient Requirements of Beef Cattle. Nat. Res. Counc., Washington, D.C.

Obioha, F.C., D.C. Clanton, L.R. Rittenhouse, and C.L. Streeter. 1970. Sources of variation in chemical composition of forage ingested by esophageal fistulated cattle. J. Range Manage. 23:133.

Raleigh, R.J., R.J. Kartchner, and L.R. Rittenhouse. 1980. Chromic oxide in range nutrition studies. Oregon Agr. Exp. Sta. Bull. 641 (In Press).

Rittenhouse, L.R. 1969. The influence of supplemental protein and energy on intake and digestibility of winter range forage. Ph.D. Thesis, Univ. of Nebraska, Lincoln.

Rittenhouse, L.R., D.C. Clanton, and C.L. Streeter. 1970. Intake and digestibility of winter range forage by cattle with and without supplements. J. Anim. Sci. 31:1215.

Scales, G.H., A.H. Denham, C.L. Streeter, and G.M. Ward. 1974. Winter supplementation of beef calves on Sandhill range. J. Anim. Sci. 38:442.

Steel, R.G.D., and J.H. Torrie. 1960. Principles and Procedures of Statistics. McGraw-Hill Book Co., New York.

Streeter, C.L., D.C. Clanton, and O.E. Hoehne. 1968. Influence of advance in season on nutritive value of forage consumed by cattle grazing western Nebraska native range. Nebraska Agr. Exp. Sta. Bull. 227.

Tilley, J.M.A., and R.A. Terry. 1963. A two-stage technique for the in vitro digestion of forage crops. J. Brit. Grassl. Soc. 18:104.

Yates, D.A., and J.D. Wallace. 1978. Cattle diets on irrigated pasture. J. Range Manage. 31:213. 